OPEN ACCESS

Edited by:

Prasat Kittakoop,

Chulabhorn Graduate

Institute, Thailand

Reviewed by:

Yongbo Xue,

Huazhong University of Science and

Technology, China

Hou-Wen Lin,

Shanghai Jiao Tong University, China

*Correspondence:

Zeping Xie

zepingxie@sina.com

Shumin Zhang

shumin_zhang@outlook.com

Specialty section:

This article was submitted to

Organic Chemistry,

a section of the journal

Frontiers in Chemistry

Received: 26 March 2020

Accepted: 08 June 2020

Published: 04 August 2020

Citation:

Guo L, Zhang L, Yang Q, Xu B, Fu X, Liu M, Li Z, Zhang S and Xie Z (2020) Antibacterial and Cytotoxic Bridged and Ring Cleavage Angucyclinones

From a Marine Streptomyces sp.

Front. Chem. 8:586.

doi: 10.3389/fchem.2020.00586

\section{Antibacterial and Cytotoxic Bridged and Ring Cleavage Angucyclinones From a Marine Streptomyces sp}

\author{
Lin Guo ${ }^{1}$, Lu Zhang ${ }^{1}$, Qiaoli Yang ${ }^{2}$, Bo Xu ${ }^{2}$, Xinzhen Fu ${ }^{1}$, Ming Liu ${ }^{1}, \mathrm{Zhi}_{\mathrm{Li}}{ }^{1}$, \\ Shumin Zhang ${ }^{1 *}$ and Zeping Xie ${ }^{1 *}$ \\ ${ }^{1}$ School of Pharmacy, Binzhou Medical University, Yantai, China, ${ }^{2}$ College of Life Sciences, Yantai University, Yantai, China
}

Chemical investigation of a marine-derived Streptomyces sp. KCB-132, cultivated in liquid ISP2 medium, had led to the discovery of three C-ring cleavage angucyclinone $\mathrm{N}$-heterocycles, pratensilins $\mathrm{A}-\mathrm{C}$, with a novel spiro indolinone-naphthofuran skeleton. Addition of $50 \mu \mathrm{M} \mathrm{LaCl} 3$ to the same medium and subsequent chemical analysis of this strain returned a new member of this rare class, pratensilin $D(\mathbf{1})$, along with two new angucyclinone derivatives, featuring ether-bridged (2) and A-ring cleavage (3) structural properties. Their structures and absolute configurations were assigned by spectroscopic analysis, single-crystal $\mathrm{X}$-ray diffractions, and equivalent circulating density (ECD) calculations. (+)- and (-)-1, a pair of enantiomeric nitrogen-containing angucyclinones, exhibited different strengths of antibacterial and cytotoxic activities.

Keywords: angucyclinones, oxygen bridge, ring cleavage, structure elucidation, Streptomyces pratensis, antibacterial activity, cytotoxicity

\section{INTRODUCTION}

Angucyclines and angucyclinones (sugarless) represent the largest family of type II polyketide synthase (PKS)-engineered natural products (Rohr and Thiericke, 1992; Krohn and Rohr, 1997; Kharel et al., 2012), which share a characteristic tetracyclic benz $[a]$ anthracene core and exhibit a wide range of biological activities (Shaaban et al., 2012; Ma et al., 2015; Xie et al., 2016; Yixizhuoma et al., 2017; Liu et al., 2019; Wu et al., 2019). Actinobacteria are the exclusive producers of angucyclines and angucyclinones that have been proven to be a prolific source of antibiotics for the production of $45 \%$ of all reported microbial active metabolites (Bérdy, 2005; Arens et al., 2013). However, only a few such metabolites are detected in the laboratory due to conditional or low production of most metabolites biosynthesized by cryptic gene clusters (Helge et al., 2002; Demain and Sanchez, 2009; Newman and Cragg, 2012; Bethany and Mohammad, 2017). Rare earth, such as scandium, was reported to be an effective factor that induces or stimulates the production of secondary metabolites (Kawai et al., 2007).

Our previous chemical analysis of the metabolites from marine actinomycete Streptomyces pratensis KCB-132 have led to the discovery of three pairs of unprecedented ring C-modified angucyclinone $\mathrm{N}$-heterocycles, (+)- and (-)-pratensilins A-C. Addition of the rare earth, lanthanum, to the liquid ISP2 medium and repeated purification of the organic extract of this strain resulted in the isolation of two new ring cleavage angucyclinones, named $( \pm)$-pratensilin $\mathrm{D}(\mathbf{1})$ and pratensinon A (3), and a new ether-bridged analog, kiamycin E (2), together with two known angucyclinones tetrangulol (4) and 8-O-methyltetrangulol (5) (Figure 1). Herein, we report the isolation, structure characterization, and biological activity of compounds $\mathbf{1 - 3}$, and a plausible biogenetic pathway for $\mathbf{1}$ and $\mathbf{2}$ is also proposed. 

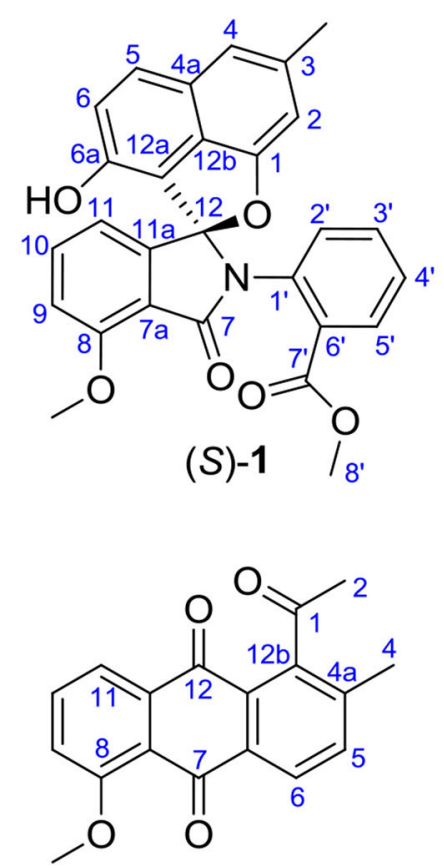

3

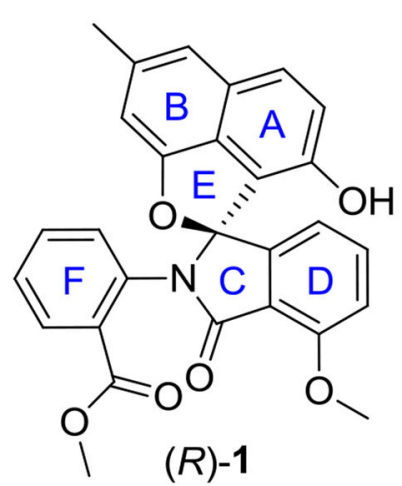<smiles>Cc1cc(O)c2c3c(ccc2c1)C(=O)c1c(O)cccc1C3=O</smiles>

4

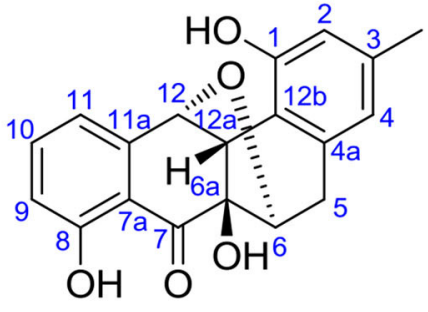

2<smiles>COc1cccc2c1C(=O)c1ccc3cc(C)cc(O)c3c1C2=O</smiles>

5

FIGURE 1 | Structures of the isolated angucyclinones.

\section{RESULTS AND DISCUSSION}

Compound 1 was obtained as a colorless solid. Its molecular formula of $\mathrm{C}_{28} \mathrm{H}_{21} \mathrm{O}_{6} \mathrm{~N}$ was established from the positiveion HRESIMS peak at $\mathrm{m} / z 468.14418[\mathrm{M}+\mathrm{H}]^{+}$(calcd for $\left.\mathrm{C}_{28} \mathrm{H}_{22} \mathrm{O}_{6} \mathrm{~N}, 468.14471\right)$. The ${ }^{1} \mathrm{H},{ }^{13} \mathrm{C}$, and heteronuclear single quantum coherence (HSQC) NMR spectra of 1 displayed one tertiary methyl at $\delta 2.35$, two methoxy groups at $\delta 3.75$ and 3.97 , and 11 aromatic methines $(\delta 7.61,7.55,7.54,7.39,7.31,7.25,7.15$, $7.08,6.96,6.60$, and 6.41), as well as one exchangeable proton at $\delta 10.11$. The ${ }^{13} \mathrm{C}$ NMR spectrum indicated the presence of two carbonyls at $\delta 165.1$ and 166.4 and 12 quaternary carbons between $\delta 103.7$ and 157.2 (Table 1). Interpretation of the ${ }^{1} \mathrm{H}$ ${ }^{1} \mathrm{H}$ COrrelation SpectroscopY (COSY) spectrum permitted three isolated fragments to be established. The first fragment, a 1,2,3trisubstituted benzene ring (ring D) was assigned by ${ }^{1} \mathrm{H}-{ }^{1} \mathrm{H}$ COSY cross-peaks for $\mathrm{H}-9 / \mathrm{H}-10 / \mathrm{H}-11$ along with heteronuclear multiple bond correlations (HMBCs) from $\mathrm{H}-9$ to $\mathrm{C}-7 \mathrm{a}$ and from $\mathrm{H}-10$ to C-8 and C-11a. Next, ${ }^{1} \mathrm{H}_{-}{ }^{1} \mathrm{H}$ COSY cross-peaks for $\mathrm{H}-$ $2^{\prime} / \mathrm{H}-3^{\prime} / \mathrm{H}-4^{\prime}$ and $\mathrm{H}-5^{\prime}$ along with $\mathrm{HMBC}$ couplings from $\mathrm{H}-2^{\prime}$ to C- $6^{\prime}$ and from $\mathrm{H}-5^{\prime}$ to C-1' allowed the constitution of a second benzene ring (ring F). The last fragment was established based on ${ }^{1} \mathrm{H}-{ }^{1} \mathrm{H}$ COSY cross-signals between $\mathrm{H}-5$ and $\mathrm{H}-6$ in combination with HMBCs from $\mathrm{H}-5$ to $\mathrm{C}-6 \mathrm{a}$ and $\mathrm{C}-12 \mathrm{~b}$ and from $\mathrm{H}-6$ to $\mathrm{C}-$ $4 \mathrm{a}$ and $\mathrm{C}-12 \mathrm{a}$, resulting in a third benzene ring as ring $\mathrm{B}$, which shared double bond $\Delta^{4 \mathrm{a}, 12 \mathrm{~b}}$ with a methyl benzene moiety (ring A) to fuse into a naphthalene system, as indicated by $\mathrm{HMBCs}$ from $\mathrm{H}-2$ to $\mathrm{C}-1$ and $\mathrm{C}-12 \mathrm{~b}$, from $3-\mathrm{CH}_{3}$ to $\mathrm{C}-2, \mathrm{C}-3$, and $\mathrm{C}-4$, and from $\mathrm{H}-4$ to $\mathrm{C}-4 \mathrm{a}$ (Figure $2 \mathrm{~A}$ ).
In addition, key HMBCs from $\mathrm{H}-9$ to the carbonyl carbon C-7 $(\delta 165.1)$ and from $\mathrm{H}-11$ to the deshielded carbon C-12 ( $\delta$ 104.6) extended ring D to C-7 and C-12; these two carbons had to be connected by an oxygen or a nitrogen atom to form either an isobenzofuran-1-one or an isoindolin-1-one ring system in line with both the chemical shifts and the molecular composition. However, both ring systems had appeared in the structures of C-ring cleavage angucyclinones produced by the same strain, previously. Moreover, no obvious correlations were observed between ring $\mathrm{F}$ and other ring systems in the ${ }^{1} \mathrm{H}_{-}{ }^{1} \mathrm{H}$ COSY and HMBC spectra, which made it problematic to assign the complete structure by spectroscopic analysis.

Finally, the structure of $\mathbf{1}$ was elucidated by X-ray crystallographic analysis (Figure 2B). Slow evaporation of a $\mathrm{MeOH} / \mathrm{CH}_{2} \mathrm{Cl}_{2}$ solution of 1 provided suitable crystals. $\mathrm{X}$-ray experiment revealed that $\mathbf{1}$ was composed of a methyl benzoate moiety attached to a spiro indolinone-naphthofuran core skeleton. Additionally, the X-ray data exhibited a centrosymmetric space group $\mathrm{C} 12 / \mathrm{cl}$, supporting a racemic nature. Subsequent optical resolution of $\mathbf{1}$ was achieved by high-performance liquid chromatography (HPLC) equipped with a chiral column to give (+)-1 and (-)-1. Based on the analogy to pratensilins $\mathrm{A}-\mathrm{C}$, we suggest that the absolute configurations for the two isomers can be assigned as (+)-S-1 and $(-)-R-\mathbf{1}$ for a biogenetic reasoning. As in pratensilins $\mathrm{A}-\mathrm{C}$, the $(S)$-enantiomers have positive optical rotations, while the $(R)$-enantiomers share consistently negative optical rotations (Zhang et al., 2017). This assignment was also confirmed by equivalent circulating density (ECD) calculations using the 
TABLE 1 | ${ }^{1} \mathrm{H}(600 \mathrm{MHz})$ and ${ }^{13} \mathrm{C}(150 \mathrm{MHz})$ NMR Data of Compounds 1-3.

\begin{tabular}{|c|c|c|c|c|c|c|}
\hline No. & \multicolumn{2}{|c|}{$1^{a}$} & \multicolumn{2}{|c|}{$2^{a}$} & \multicolumn{2}{|c|}{$3^{\mathrm{b}}$} \\
\hline 1 & 156.4 & & 154.3 & & 205.7 & \\
\hline 2 & 103.7 & $6.41, s$ & 113.4 & $6.48, \mathrm{~s}$ & 31.1 & $2.59, \mathrm{~s}$ \\
\hline 3 & 136.0 & & 137.0 & & & \\
\hline 4 & 115.7 & $6.96, d(1.0)$ & 120.4 & $6.45, \mathrm{~s}$ & 19.0 & $2.38, \mathrm{~s}$ \\
\hline 6 & 121.4 & 7.08, d (8.6) & 74.8 & 4.06, t (2.8) & 127.7 & $8.22, d(7.9)$ \\
\hline $6 a$ & 149.3 & & 81.9 & & 133.4 & \\
\hline 7 & 165.1 & & 205.8 & & 181.8 & \\
\hline $7 a$ & 116.5 & & 114.8 & & 121.0 & \\
\hline 11 & 115.0 & $6.60, \mathrm{dd}(7.9,0.5)$ & 117.2 & $6.98, d(7.9)$ & 120.1 & $7.89, \mathrm{~d}(7.7,1.1)$ \\
\hline $11 a$ & 146.4 & & 148.8 & & 135.3 & \\
\hline 12 & 104.6 & & 85.0 & $4.86, \mathrm{~s}$ & 183.8 & \\
\hline $12 \mathrm{a}$ & 114.8 & & 49.0 & $3.65, \mathrm{~s}$ & 129.1 & \\
\hline $12 b$ & 128.2 & & 120.9 & & 142.6 & \\
\hline $1^{\prime}$ & 133.8 & & & & & \\
\hline $2^{\prime}$ & 131.2 & $7.15, \mathrm{dd}(7.7,1.4)$ & & & & \\
\hline $3^{\prime}$ & 132.5 & 7.39, td $(7.7,1.6)$ & & & & \\
\hline $4^{\prime}$ & 129.1 & $7.31, \operatorname{td}(7.7,1.4)$ & & & & \\
\hline $5^{\prime}$ & 130.4 & $7.61, \mathrm{dd}(7.7,1.6)$ & & & & \\
\hline $6^{\prime}$ & 132.9 & & & & & \\
\hline
\end{tabular}

${ }^{a}$ Recorded in DMSO-d $6,{ }^{b}$ Recorded in $\mathrm{CDCl}_{3}$.

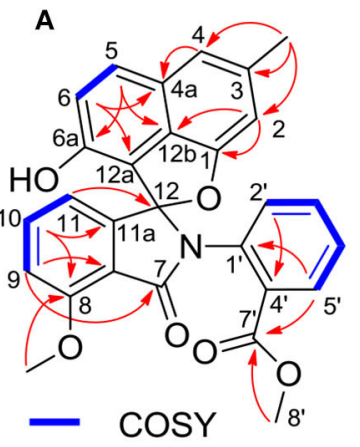

$\longrightarrow$ HMBC
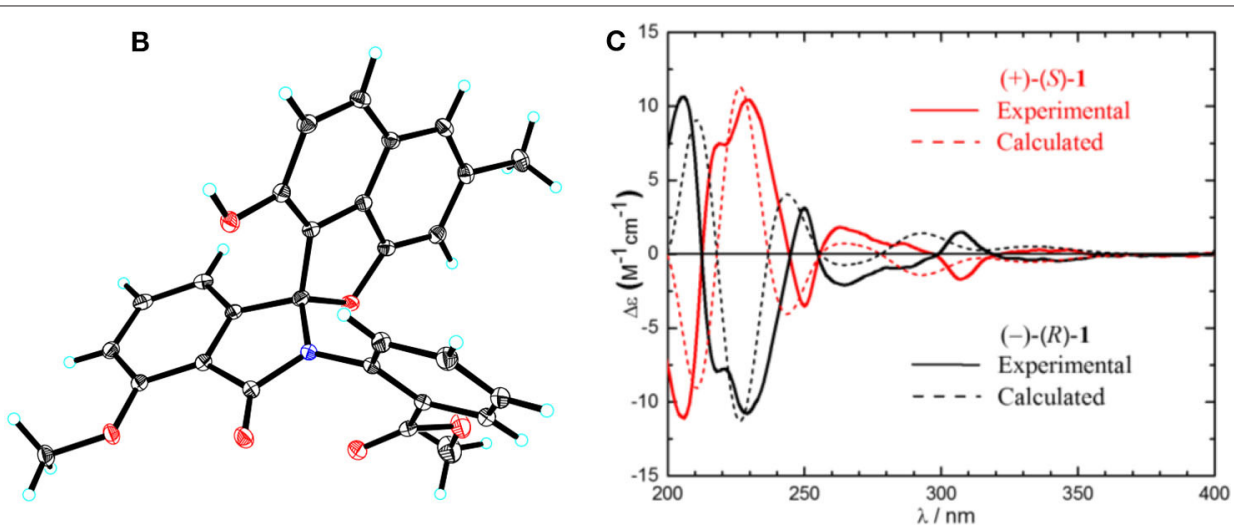

FIGURE 2 | (A) Key ${ }^{1} \mathrm{H}^{-1} \mathrm{H}$ COrrelation SpectroscopY (COSY) and heteronuclear multiple bond correlations (HMBCs) of 1. (B) X-ray crystal structure of (-)-1. (C) Experimental and calculated equivalent circulating density (ECD) spectra for $(+)-(S)-\mathbf{1}$ and $(-)-(R)-\mathbf{1}$. 
same ECD computational approach as for pratensilins A-C. In fact, the CD spectra of (+)-1 and (-)-1 reproduced well with those of pratensilins $\mathrm{A}-\mathrm{C}$ apart from a systematic wavelength shift (Figure 2C). Herein, we suggest to name pratensilin D for compound 1.

Compound $\mathbf{2}$ was isolated as a pale-yellow solid. Highresolution electrospray ionization mass spectrometry (HRESIMS) provided a molecular formula of $\mathrm{C}_{19} \mathrm{H}_{16} \mathrm{O}_{6}$ $\left[m / z 325.10740[\mathrm{M}+\mathrm{H}]^{+}\right.$, calcd for $\left.\mathrm{C}_{19} \mathrm{H}_{17} \mathrm{O}_{5}, 325.10760\right]$ requiring 12 degrees of unsaturation. The ${ }^{13} \mathrm{C}$ and distortionless enhancement by polarization transfer (DEPT) NMR spectra exhibited 19 carbon signals for one methyl, one methylene, eight methines including five aromatic methines, one carbonyl carbon, and eight quaternary carbons, of which seven are $\mathrm{sp}^{2}$ aromatic carbons (Table 1). Since the aromatic carbons and the carbonyl accounted for 7 of the 12 degrees of unsaturation, compound 2 must be pentacyclic. In the ${ }^{1} \mathrm{H}$ NMR spectrum, the characteristic signals for $o$-coupled protons at $\delta 6.97(\mathrm{H}-9), \delta 7.56(\mathrm{H}-10)$, and $\delta 6.98(\mathrm{H}-11)$ indicated the presence of a 1, 2, 3-trisubstituted benzene ring $\mathrm{D}$, while a typical olefinic methyl resonance at $\delta$ $2.18\left(3-\mathrm{CH}_{3}\right)$, which showed long-range couplings with two aromatic singlets at $\delta 6.48(\mathrm{H}-2)$ and $\delta 6.45(\mathrm{H}-4)$, was assigned to benzene ring $\mathrm{A}$ as observed in $\mathbf{1}$ (Figure 1). An additional ${ }^{1} \mathrm{H}_{-}{ }^{1} \mathrm{H}$ COSY cross-peak between $\mathrm{H}_{2}-5$ and $\mathrm{H}-6$ along with HMBCs from $\mathrm{H}_{2}-5$ to C-4a, from $\mathrm{H}-6$ to C-6a, and from $\mathrm{H}-12 \mathrm{a}$ to $\mathrm{C}-6 \mathrm{a}$ and $\mathrm{C}-12 \mathrm{~b}$ suggested that the cyclohexene ring $\mathrm{B}$ is joined to ring $\mathrm{A}$ by sharing the double bond between $\mathrm{C}-4 \mathrm{a}$ and $\mathrm{C}-12 \mathrm{~b}$. Furthermore, ring systems $\mathrm{A} / \mathrm{B}$ and $\mathrm{D}$ were linked by ring $\mathrm{C}$ (C-7 and C-12) to form an angucyclinone skeleton evidenced by HMBCs from both H-6 and H-9 to the carbonyl carbon C-7 ( $\delta$ 205.8) and from H-12 to C-11 and C-12a (Figure 3A).

Positioning of two hydroxyl groups at C-1 ( $\delta$ 154.3) and C6a $(\delta 81.9)$ was facilitated by HMBCs from $1-\mathrm{OH}$ to $\mathrm{C}-1$ and from $6 \mathrm{a}-\mathrm{OH}$ to $\mathrm{C}-6 \mathrm{a}$, respectively. The remaining phenolic $\mathrm{OH}$ group at $\delta 11.69$ had to be attached to the oxygenated aromatic carbon C-8 to fit in the deshielded characteristic of C-8 ( $\delta$ 162.2). At this point of the structure elucidation, only one oxygen atom was left as defined by the molecular formula, the two downfield methine carbons C- 6 and C-12 must be joined by an oxygen bridge in agreement with both the chemical shifts of C-6 ( $\delta 74.8)$ and C-12 ( $\delta 85.0)$, completing the pentacyclic requirement of 2 , which was further supported by three-bond HMBCs coupling from H-6 to C-12 (and vice versa). Taken together, a rare 6,12epoxybenz $[a]$ anthracene ring topology was expected; we thus suggest the successive name kiamycin E for 2 .

The relative configuration of $\mathbf{2}$ was tentatively assigned by nuclear Overhauser effect (NOE) correlations (Figure 3A). The NOE contacts of $\mathrm{H}-12$ with $\mathrm{H}-12 \mathrm{a}$ and of $\mathrm{H}-12 \mathrm{a}$ with $6 \mathrm{a}-\mathrm{OH}$ indicated that $\mathrm{H}-12, \mathrm{H}-12 \mathrm{a}$, and $6-\mathrm{OH}$ have common $\beta$-orientations, which require an $\alpha$-orientation of the bridged C-6/12 bond; consequently, H-6 was defined as $\beta$, although no NOE was observed between H-6 and 6a$\mathrm{OH}$. This assignment was finally confirmed by single-crystal X-ray diffraction experiment (Figure 3B). Additionally, the absolute configuration was assigned as $6 S, 6 \mathrm{a} R, 12 R$, and $12 \mathrm{a} S$, respectively.

Compound 3 was isolated as a yellow powder. Its molecular formula was assigned to be $\mathrm{C}_{18} \mathrm{H}_{14} \mathrm{O}_{4}$ based on HRESIMS $[\mathrm{m} / z$ 295.09677 $[\mathrm{M}+\mathrm{H}]^{+}$, calcd for $\left.\mathrm{C}_{18} \mathrm{H}_{15} \mathrm{O}_{4}, 295.09703\right]$. In the ${ }^{13} \mathrm{C}$ NMR spectrum, the typical carbonyl carbon resonances at $\delta 181.8$ and 183.8 indicated the presence of an anthraquinone skeleton. A comparison of the ${ }^{1} \mathrm{H}$ and ${ }^{13} \mathrm{C}$ NMR spectra of 3 and the known derivative 4 revealed superimposable resonances for the anthraquinone moiety, apart from ring A. Resonances at $\delta 31.1$ and 205.7 indicated the presence of an acetyl group, which was positioned at $\mathrm{C}-12 \mathrm{~b}$ of ring $\mathrm{B}$ by $\mathrm{HMBC}$ from 2$\mathrm{CH}_{3}$ to the carbonyl carbon $\mathrm{C}-1$ and the quaternary carbon C$12 \mathrm{~b}\left(\delta\right.$ 142.6). An additional $\mathrm{HMBC}$ from $4-\mathrm{CH}_{3}(\delta 2.38)$ to $\mathrm{C}-$ $4 \mathrm{a}(\delta$ 139.1) permitted the methyl group to be located at C-4a (Figure 4). At this point, all carbon and proton resonances of 3 were assigned, leading to a structure feature of A-ring cleavage, which is very rare in the angucyclinone/angucycline family. For better comparison, compound $\mathbf{3}$ was trivially named pratensinon $\mathrm{A}$, and the conventional angucyclinone numbering was used for compounds $\mathbf{1 - 3}$ in this paper.

Compound 1 represents a C-ring cleavage angucyclinone with a rare nitrogen-containing spiro ring system that is distinct from the bridged counterpart 2 . However, these two compounds might originate from the same angucyclinone precursor tetrangulol (4), which together with 8-O-methyltetrangulol (5), were isolated
A
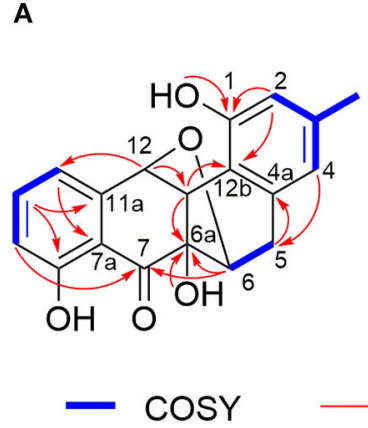
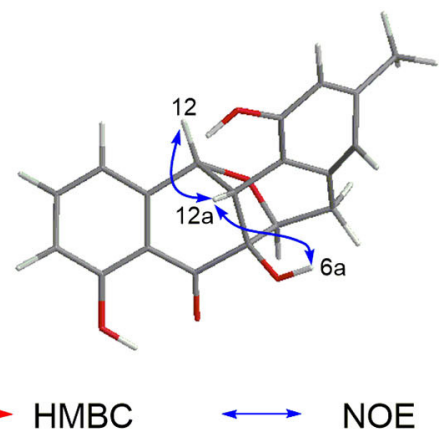

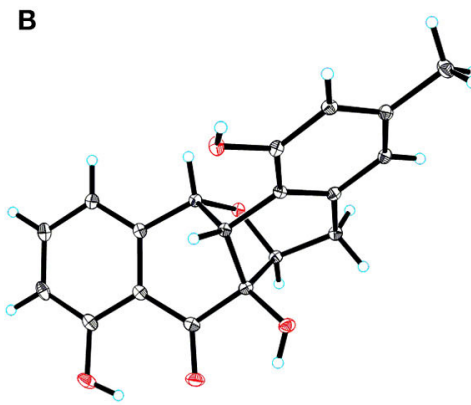

FIGURE 3 | (A) Key ${ }^{1} \mathrm{H}-{ }^{1} \mathrm{H}$ COrrelation SpectroscopY (COSY), heteronuclear multiple bond correlation (HMBC), and nuclear Overhauser effect (NOE) correlations of 2. (B) X-ray crystal structure of 2 . 
from the same strain in parallel, and a plausible biosynthetic pathway is proposed in Scheme 1. Starting with methylation on 4 results in ester $\mathbf{5}$, which on Baeyer-Villiger oxidation gives lactone a, and continues through hydrolytic cleavage to form intermediate $\mathbf{b}$, followed by acetalization and condensation at C7 ketone by 2-(methoxycarbonyl) aniline to introduce a nitrogen atom in $\mathbf{c}$, which can be intramolecularly cyclized into pratensilin D. In another pathway, oxidation on the double bond $\Delta^{5,6}$ and $\Delta^{6 a, 12 a}$ furnishes epoxide $\mathbf{d}$, which undergoes a series of reduction to yield intermediate $\mathbf{f}$, and subsequent cyclization gives rise to kiamycin $\mathrm{E}$.

Angucyclines and angucyclinones possess not only great structural diversity but also a broad range of biological activities, predominantly anticancer and antibacterial activities (Kharel et al., 2012). Compounds 1-3 were thus screened for activity against Gram-positive (Bacillus cereus CMCC 32210, Staphylococcus aureus CMCC 26003) bacteria and yeast (Candida albicans CMCC 98001), as well as five human cancer cell lines

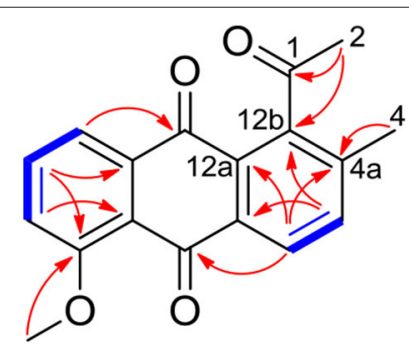

3

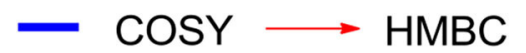

FIGURE 4 | Key ${ }^{1} \mathrm{H}^{-1} \mathrm{H}$ COrrelation SpectroscopY (COSY) and heteronuclear multiple bond correlations (HMBCs) of $\mathbf{3}$.
(NCI-H460, PANC-1, Colon 38, Hela, and HepG2) (Table 2). $(-)-1$ exhibited selective inhibitory activity against $B$. cereus CMCC 32210 with a minimum inhibitory concentration (MIC) value of $4 \mu \mathrm{g} / \mathrm{ml}$; in contrast, its enantiomer (+)-1 showed no efficacy against all tested strains up to $64 \mu \mathrm{g} / \mathrm{ml}$, so did 2 and 3. Furthermore, (-)-1 exhibited moderate cytotoxicity to NCI$\mathrm{H} 460$ and HepG2 cell lines with respective $\mathrm{IC}_{50}$ values of 4.6 and $9.3 \mu \mathrm{g} / \mathrm{ml}$, while $(+)-1$ was only less active to NCI-H460 cells with an $\mathrm{IC}_{50}$ value of $9.2 \mu \mathrm{g} / \mathrm{ml} .3$ displayed cytotoxic activity to Colon 38 and Hela cells, with $\mathrm{IC}_{50}$ values of 7.3 and $10.3 \mu \mathrm{g} / \mathrm{ml}$, respectively. However, 2 showed no inhibitory effect against all tested cell lines in the testing concentration range $\left(\mathrm{IC}_{50}\right.$ $>50 \mu \mathrm{g} / \mathrm{ml}$ ).

In summary, five angucyclinones, including three new compounds (1-3) were isolated from the ISP2 medium fermentation with addition of $50 \mu \mathrm{M} \mathrm{LaCl}$ of the marinederived Streptomyces pratensis strain KCB-132. The new compounds possessed different types of structural properties including oxygen bridge (2) and C-ring and A-ring cleavage (1 and 3), respectively. (+)- and (-)-pratensilin D (1), a pair of enantiomeric angucyclinone $N$-heterocycles, were further separated by chiral HPLC and showed different strengths of biological activities. The new structural properties, especially Aring and C-ring cleavage disrupting the characteristic tetracyclic ring frame, expand the structural diversity of angucyclines and angucyclinones and provide insight into their structureactivity relationship.

\section{EXPERIMENTAL SECTION}

\section{General Experimental Procedures}

Opitical rotations were measured on an Autopol VI (Serial \#91058) manufactured by Rudolph Research Analytical, Hackettstown, NJ, USA. UV spectra were recorded by a Shimadzu UV-2401PC spectrometer. CD spectra were recorded using a JASCO J-810 spectropolarimeter. NMR spectra were

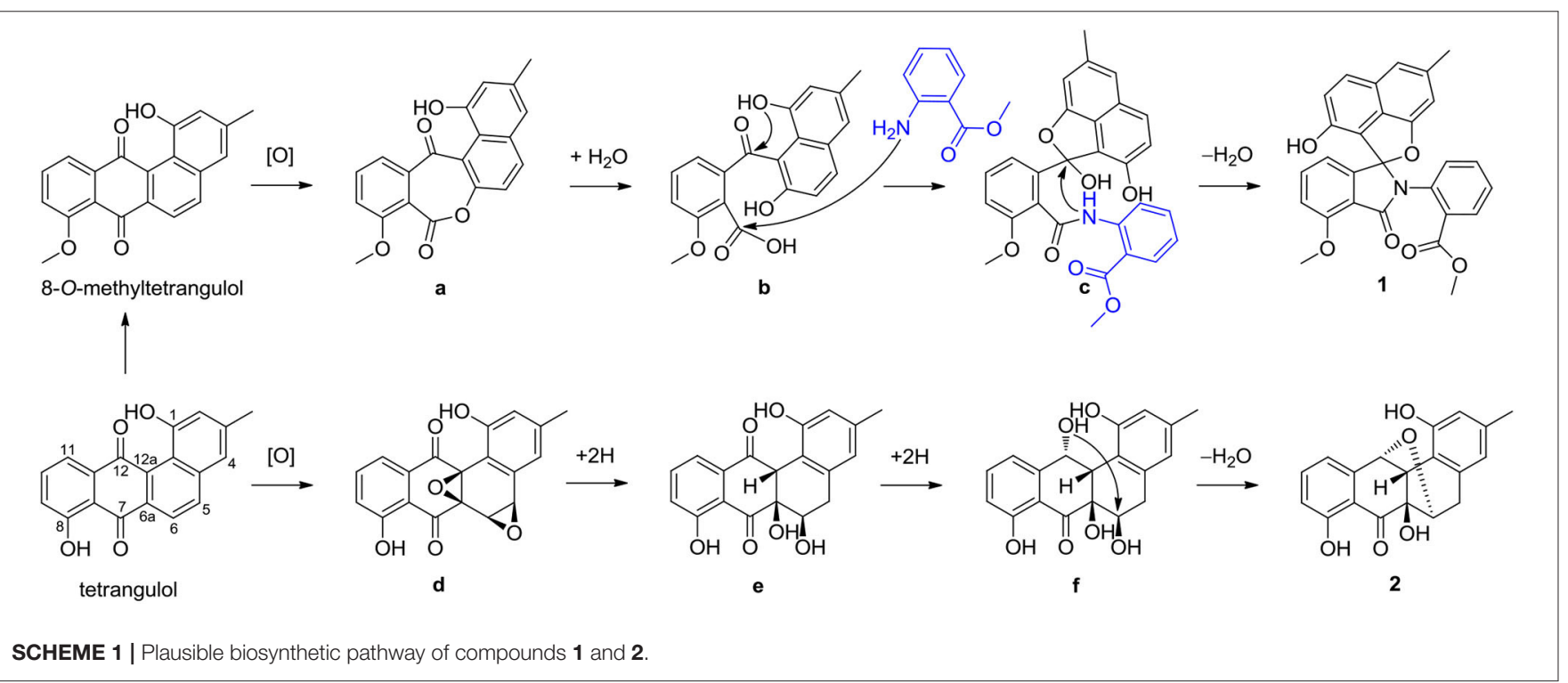


TABLE 2 | Cytotoxic and antimicrobial activities of compounds (+)- and (-)-1, 2, and $\mathbf{3}$.

\begin{tabular}{|c|c|c|c|c|c|c|c|c|}
\hline \multirow[t]{2}{*}{ Compounds } & \multicolumn{5}{|c|}{ Cytotoxic activity $\left(\mathrm{IC}_{50} \mu \mathrm{g} / \mathrm{ml}\right)$} & \multicolumn{3}{|c|}{ Antimicrobial activity (MIC $\mu \mathrm{g} / \mathrm{ml}$ ) } \\
\hline & $\mathrm{NCl}-\mathrm{H} 460$ & PANC-1 & HepG2 & Colon38 & Hela & C. albicans & S. aureus & B. cereus \\
\hline$(+)-1$ & 9.4 & NT & $>50$ & NT & NT & $>64$ & $>64$ & $>64$ \\
\hline$(-)-1$ & 4.9 & NT & 9.3 & NT & NT & $>64$ & $>64$ & 4 \\
\hline 2 & NT & NT & $>50$ & $>50$ & $>50$ & $>64$ & $>64$ & $>64$ \\
\hline 3 & NT & NT & $>50$ & 7.3 & 10.3 & $>64$ & $>64$ & $>64$ \\
\hline Nystatin & NT & NT & NT & NT & NT & 4 & NT & NT \\
\hline Penicillin & NT & NT & NT & NT & NT & NT & 4 & 2 \\
\hline Adriamycin & 0.03 & 0.27 & 0.81 & 0.20 & 0.02 & NT & NT & NT \\
\hline
\end{tabular}

MIC, minimum inhibitory concentration; NT, not tested.

recorded on Bruker Avance III 600 spectrometers. Electrospray ionization (ESI)-high-resolution mass spectrometry (HRMS) were recorded on an Agilent G6230 TOF spectrometer. Single crystal X-ray crystallography was determined on SMART APEX II DUO X-ray single crystal diffractometer using $\mathrm{Cu}$ $\mathrm{K} \alpha$ radiation. Preparative HPLC was performed on a Waters 2489 series instrument with a UV/Visible detector, using a reversed-phase C18 column (Phenomenex, $250 \mathrm{~mm} \times 21.2 \mathrm{~mm}$, $5 \mu \mathrm{m})$. Chiral HPLC was carried out on an Agilent 1260 liquid chromatograph, utilizing chiral analytical columns $[(R, R)$ WHELK-01 column, $4.6 \mathrm{~mm} \times 250 \mathrm{~mm}, 10 \mu \mathrm{m}, 100 \mathrm{~A}]$.

\section{Cultivation and Culture Extraction}

Streptomyces sp. strain KCB-132 was isolated from a sediment sample collected off Kiaochow Bay, China, as described previously (Zhang et al., 2017). The sequence is deposited in GenBank under accession no. KX033803. The strain KCB132 was cultured in seawater-based ISP2 medium ( $5 \mathrm{~g}$ of malt extract, $4 \mathrm{~g}$ of yeast extract, $4 \mathrm{~g}$ of glucose, $500 \mathrm{ml}$ of deionized water, and $500 \mathrm{ml}$ of seawater, $\mathrm{pH} \mathrm{7.8)} \mathrm{with} \mathrm{the} \mathrm{addition} \mathrm{of}$ $50 \mu \mathrm{M}$ lanthanum chloride, at a total volume of $21.6 \mathrm{~L}(72$ $\times 0.3 \mathrm{~L}$ ), for 10 days at $28^{\circ} \mathrm{C}$. The culture broth was filtered to provide filtrate and mycelium. The filtrate was absorbed onto XAD-16 amberlite resin, and the resin was eluted with methanol, then dried out methanol under reduced pressure. The resulting aqueous layer was extracted with ethyl acetate, while the mycelium was extracted by ethyl acetate under ultrasonic radiation directly; both ethyl acetate phases were combined to yield 7.2 g crude extract.

\section{Isolation of Compounds 1-5}

The extract $(7.2 \mathrm{~g})$ was fractioned by silica gel column chromatography ( $40 \mathrm{~g}$ ) and eluted with a step gradient of $\mathrm{CH}_{2} \mathrm{Cl}_{2}$ and $\mathrm{MeOH}$. The $\mathrm{CH}_{2} \mathrm{Cl}_{2} / \mathrm{MeOH}$ 99:1 fraction was purified by preparative HPLC (Gemini, C18, $21.2 \mathrm{~mm} \times 250 \mathrm{~mm}, 5 \mu \mathrm{m}$, UV $=210 \mathrm{~nm}$ ), eluting with $60 \% \mathrm{MeOH}$ in $\mathrm{H}_{2} \mathrm{O}$ to afford pratensilin $\mathrm{D}(1,1.6 \mathrm{mg})$, tetrangulol $(4,4.1 \mathrm{mg})$, and 8 - $O$-methyltetrangulol (5, 3.6 mg). The $\mathrm{CH}_{2} \mathrm{Cl}_{2} / \mathrm{MeOH}$ 49:1 fraction was purified by the same preparative HPLC system eluting with $45 \% \mathrm{MeOH}$ in $\mathrm{H}_{2} \mathrm{O}$ to give kiamycin $\mathrm{E}(2,1.2 \mathrm{mg})$ and pratensinon $\mathrm{A}$ (3, $0.6 \mathrm{mg})$. Chiral resolution of $\mathbf{1}$ was performed on Agilent analytical HPLC system $[(R, R)$ WHELK-01 column, $4.6 \mathrm{~mm}$ $\times 250 \mathrm{~mm}, 10 \mu \mathrm{m}, 100 \mathrm{~A}$, iso-Pro-OH $/ \mathrm{n}$-Hexane $=20: 80,1.0$ $\mathrm{ml} / \mathrm{min}, \mathrm{UV}=210 \mathrm{~nm}]$ to obtain optically pure $(+)-1(0.6 \mathrm{mg})$ and (-)-1 (0.6 mg).

$(+)$-Pratensilin D $[(+)-1]$ : colorless solid; $[\alpha]_{\mathrm{D}}^{25}+50.5$ (MeOH, c 0.2); UV (acetonitrile) $\lambda_{\max }(\log \varepsilon) 211$ (3.8), 241 (3.5), $302(2.8), 343(2.3) \mathrm{nm} ;{ }^{1} \mathrm{H}-\mathrm{NMR}\left(600 \mathrm{MHz}, \mathrm{DMSO}-d_{6}\right)$ and ${ }^{13} \mathrm{C}-$ NMR (150 MHz, DMSO- $\left.d_{6}\right)$ data, see Table S1; HRESIMS [M + $\mathrm{H}]^{+}, m / z$ 468.14418 (calcd for $\mathrm{C}_{28} \mathrm{H}_{22} \mathrm{O}_{6} \mathrm{~N}, 468.14471$ ).

(-)-Pratensilin D $[(-)-1]$ : colorless solid; $[\alpha]_{\mathrm{D}}^{25}-61.8(\mathrm{MeOH}$, c 0.2); UV (acetonitrile) $\lambda_{\max }(\log \varepsilon) 211$ (3.9), 241 (3.5), 302 (2.9), 345 (2.4) nm; ${ }^{1} \mathrm{H}-\mathrm{NMR}\left(600 \mathrm{MHz}, \mathrm{DMSO}-d_{6}\right)$ and ${ }^{13} \mathrm{C}-$ NMR (150 MHz, DMSO- $\left.d_{6}\right)$ data, see Table S1; HRESIMS [M + $\mathrm{H}]^{+}, m / z 468.14418$ (calcd for $\mathrm{C}_{28} \mathrm{H}_{22} \mathrm{O}_{6} \mathrm{~N}, 468.14471$ ).

Kiamycin E (2): colorless solid; $[\alpha]_{\mathrm{D}}^{25}+38.7(\mathrm{MeOH}, c$ $0.2)$; UV (acetonitrile) $\lambda_{\max }(\log \varepsilon) 203$ (3.6), 262 (2.8), 336 (2.5) nm; ${ }^{1} \mathrm{H}-\mathrm{NMR}\left(600 \mathrm{MHz}, \mathrm{DMSO}-d_{6}\right)$ and ${ }^{13} \mathrm{C}-\mathrm{NMR}(150$ $\left.\mathrm{MHz}, \mathrm{DMSO}-d_{6}\right)$ data, see Table S2; HRESIMS $[\mathrm{M}+\mathrm{H}]^{+}, m / z$ 325.10740 (calcd for $\mathrm{C}_{19} \mathrm{H}_{17} \mathrm{O}_{5}, 325.10760$ ).

Pratensinon A (3): colorless solid; UV (acetonitrile) $\lambda_{\max }(\log$ ع) 190 (3.2), 215 (3.09), 257 (3.12), 282 (2.6) nm; ${ }^{1} \mathrm{H}-\mathrm{NMR}$ $\left(600 \mathrm{MHz}, \mathrm{CDCl}_{3}\right.$ ) and ${ }^{13} \mathrm{C}-\mathrm{NMR}\left(150 \mathrm{MHz}, \mathrm{CDCl}_{3}\right)$ data, see Table S3; HRESIMS $[\mathrm{M}+\mathrm{H}]^{+}, \mathrm{m} / z 295.09677$ (calcd for $\mathrm{C}_{18} \mathrm{H}_{15} \mathrm{O}_{4}, 295.09703$ ).

\section{X-Ray Crystallographic Analysis}

Crystallographic data of 1: X-ray quality crystals were acquired by slow volatilization of a solvent mixture of $\mathrm{MeOH}$ and $\mathrm{CH}_{2} \mathrm{Cl}_{2}$. Crystal data for xzp6: $\mathrm{C}_{28} \mathrm{H}_{21} \mathrm{NO}_{6}, M=467.46, a=$ 29.4142(7) $\AA, b=12.1834(3) \AA, c=13.7172(3) \AA, \alpha=90^{\circ}$, $\beta=114.8000(10)^{\circ}, \gamma=90^{\circ}, V=4462.42(18) \AA^{3}, \mathrm{~T}=100$. (2) $\mathrm{K}$, space group $C 12 / c 1, Z=8, \mu(\mathrm{Cu} \mathrm{K} \alpha)=0.812 \mathrm{~mm}^{-1}$, 41,600 reflections measured, 4,411 independent reflections $\left(R_{\text {int }}\right.$ $=0.0440)$. The final $R_{1}$ values were $0.0419[I>2 \sigma(I)]$. The final $w R\left(F^{2}\right)$ values were $0.1594[I>2 \sigma(I)]$. The final $R_{1}$ values were 0.0446 (all data). The final $w R\left(F^{2}\right)$ values were 0.1639 (all data). The goodness of fit on $F^{2}$ was 1.450. Crystallographic data for compound $\mathbf{1}$ has been deposited in the Cambridge Crystallographic Data Centre with deposition number 1953675.

Crystallographic data of 2: X-ray quality crystals were acquired by slow volatilization of a solvent mixture of $\mathrm{MeOH}$ and $\mathrm{CH}_{2} \mathrm{Cl}_{2}$. Crystal data for xzp8: $\mathrm{C}_{19} \mathrm{H}_{16} \mathrm{O}_{5}, M=324.32, a=$ 24.9006(5) $\AA, b=8.1765(2) \AA, c=7.4089(2) \AA, \alpha=90^{\circ}, \beta=$ 
$100.7240(10)^{\circ}, \gamma=90^{\circ}, V=1482.11(6) \AA^{3}, T=100$. (2) K, space group $C 121, Z=4, \mu(\mathrm{Cu} \mathrm{K} \alpha)=0.874 \mathrm{~mm}^{-1}, 13,063$ reflections measured, 2,919 independent reflections $\left(R_{\text {int }}=0.0315\right)$. The final $R_{1}$ values were $0.0281[I>2 \sigma(I)]$. The final $w R\left(F^{2}\right)$ values were $0.0759[I>2 \sigma(I)]$. The final $R_{1}$ values were 0.0287 (all data). The final $w R\left(F^{2}\right)$ values were 0.0766 (all data). The goodness of fit on $F^{2}$ was 1.023 . Flack parameter $=0.07(5)$. Crystallographic data for compound 2 has been deposited in the Cambridge Crystallographic Data Centre with deposition number 1992536.

\section{Bioactivity Assay}

The antimicrobial assays of compounds 1-3 were tested against Gram-positive (B. cereus CMCC 32210, S. aureus CMCC 26003) bacteria and yeast (C. albicans CMCC 98001) using a microplate assay (Pierce et al., 2008). Nystatin and penicillin were used as positive controls against fungi and bacteria, respectively.

The NCI-H460 (non-small-cell lung carcinoma), PANC-1 (pancreatic cancer), HepG2 (liver hepatocellular carcinoma), Colon 38 (colon cancer), and Hela (cervical carcinoma) cells were plated at a density of 5,000 cells/well in $100 \mu \mathrm{l}$ Dulbecco's modified Eagle's medium (DMEM). All cell lines were incubated overnight then treated with various concentrations of purified compounds in triplicate. After culturing for $72 \mathrm{~h}, 20 \mu \mathrm{l} /$ well of 3-(4,5-dimethylthiazol-2-yl)-2,5-diphenyl tetrazolium bromide (MTT) solution (5 $\mathrm{mg} / \mathrm{ml}$, Sigma-Aldrich, USA) was added to each well, plate was cultured for $4 \mathrm{~h}$ at $37^{\circ} \mathrm{C}$ in a $5 \% \mathrm{CO}_{2}$ atmosphere, which was followed by adding $150 \mu \mathrm{l}$ DMSO to dissolve the formazan crystals, and shaking for $5 \mathrm{~min}$. The absorbance was recorded at $570 \mathrm{~nm}$ by a microplate reader. $\mathrm{IC}_{50}$

\section{REFERENCES}

Arens, J. C., Berru?, F., Pearson, J. K., and Kerr, R. G. (2013). Isolation and structure elucidation of satosporin $\mathrm{A}$ and $\mathrm{B}$ : new polyketides from Kitasatospora griseola. Org. Lett. 15, 3864-3867. doi: 10.1021/ol4 $01598 \mathrm{f}$

Bérdy, J. (2005). Bioactive microbial metabolites. J. Antibiot. 58, 1-26. doi: $10.1038 /$ ja.2005.1

Bethany, K. O., and Mohammad, R. S. (2017). Antibiotic dialogues: induction of silent biosyntheticgene clusters by exogenous small molecules. FEMS Microbiol. Rev. 41, 19-33. doi: 10.1093/femsre/ fuw035

Demain, A. L., and Sanchez, S. (2009). Microbial drug discovery: 80 years of progress. J. Antibiot. 62, 5-16. doi: 10.1038/ja.2008.16

Helge, B. B., Barbara, B., Regina, H., and Axel, Z. (2002). Big effects from small changes: possible ways to explore nature's chemical diversity. ChemBioChem. 3, 619-627. doi: 10.1002/1439-7633(20020703)3:7<619::AID-CBIC619>3.0.CO;2-9

Kawai, K., Wang, G., Okamoto, S., and Ochi, K. (2007). The rare earth, scandium, causes antibiotic overproduction in Streptomyces spp. FEMS Microbiol. Lett. 274, 311-315. doi: 10.1111/j.1574-6968.2007.00846.x

Kharel, M. K., Pahari, P., Shepherd, M. D., Tibrewal, N., Nybo, S. E., Shaaban, K. A., et al. (2012). Angucyclines: biosynthesis, mode-of-action, new natural products, and synthesis. J. Nat. Prod. Rep. 29, 264-325. doi: 10.1039/C1NP00068C

Krohn, K., and Rohr, J. (1997). Angucyclines: total syntheses, new structures, and biosynthetic studies of an emerging new class of antibiotics. Top. Curr. Chem. 188, 127-195. doi: 10.1007/BFb0119236 value was taken using GraphPad Prism 5 software. Adriamycin was used as a positive control.

\section{DATA AVAILABILITY STATEMENT}

The datasets presented in this study can be found in online repositories. The names of the repository/repositories and accession number(s) can be found in the article/Supplementary Material.

\section{AUTHOR CONTRIBUTIONS}

LG, LZ, and QY separated and purified the compounds. ML and ZL identified the structures. BX and XF tested cytotoxic and antimicrobial activities. SZ and ZX conceived and designed the experiments. ZX prepared the paper. All authors approved the final manuscript. All authors contributed to the article and approved the submitted version.

\section{FUNDING}

This research was funded by the Natural Science Foundation of Shandong Province, grant number ZR2018LD006.

\section{SUPPLEMENTARY MATERIAL}

The Supplementary Material for this article can be found online at: https://www.frontiersin.org/articles/10.3389/fchem. 2020.00586/full\#supplementary-material

Liu, T., Jin, J., Yang, X., Song, J., Yu, J., Geng, T., et al. (2019). Discovery of a phenylamine-incorporated angucyclinone from marine Streptomyces sp. PKU-MA00218 and generation of derivatives with phenylamine analogues. Org. Lett. 21, 2813-2817. doi: 10.1021/acs.orglett.9 b00800

Ma, M., Rateb, M. E., Teng, Q., Yang, D., Rudolf, J. D., Zhu, X., et al. (2015). Angucyclines and angucyclinones from Streptomyces sp. CB01913 featuring C-ring cleavage and expansion. J. Nat. Prod. 78, 2471-2480. doi: 10.1021/acs.jnatprod.5b00601

Newman, D. J., and Cragg, G. M. (2012). Natural products as sources of new drugs over the 30 years from 1981 to 2010. J. Nat. Prod. 75, 311-335. doi: $10.1021 / \mathrm{np} 200906 \mathrm{~s}$

Pierce, C. G., Uppuluri, P., Tristan, A. R., Wormley, F. L. Jr., Mowat, E., Ramage, G., et al. (2008). A simple and reproducible 96-well platebased method for the formation of fungal biofilms and its application to antifungal susceptibility testing. Nat. Protoc. 3, 1494-1500. doi: 10.1038/nprot.2 008.141

Rohr, J., and Thiericke, R. (1992). Angucycline group antibiotics. Nat. Prod. Rep. 9, 103-137. doi: 10.1039/np9920900103

Shaaban, K. A., Ahmed, T. A., Leggas, M., and Rohr, J. (2012). Saquayamycins G-K, cytotoxic angucyclines from Streptomyces sp. including two analogues bearing the amino-sugar rednose. J. Nat. Prod. 75, 1383-1392. doi: 10.1021/np $300316 b$

Wu, C., van der Heu, H. U., Melnik, A. V., Lübben, J., Dorrestein, P. C., Minnaard, A. J., et al. (2019). Lugdunomycin, an angucyclinederived molecule with unprecedented chemical architecture. Angew. Chem. Int. Ed. Engl. 58, 2809-2814. doi: 10.1002/anie.201 814581 
Xie, Z., Zhou, L., Guo, L., Yang, X., Qu, G., Wu, C., et al. (2016). Grisemycin, a bridged angucyclinone with a methylsulfinyl moiety from a marine-derived Streptomyces sp. Org. Lett. 18, 1402-1405. doi: 10.1021/acs.orglett.6b00332

Yixizhuoma, Ishikawa, N., Abdelfattah, M. S., and Ishibashi, M. (2017). Elmenols $\mathrm{C}-\mathrm{H}$, new angucycline derivatives isolated from a culture of Streptomyces sp. IFM 11490. J. Antibiot. 70, 601-606. doi: 10.1038/ja.2016.158

Zhang, S., Yang, Q., Guo, L., Zhang, Y., Feng, L., Zhou, L., et al. (2017). Isolation, structure elucidation and racemization of $(+)$ - and (-)-pratensilins A-C: unprecedented spiro indolinone-naphthofuran alkaloids from a marine Streptomyces sp. Chem. Commun. 53, 10066-10069. doi: 10.1039/C7C $\mathrm{C} 04983 \mathrm{H}$
Conflict of Interest: The authors declare that the research was conducted in the absence of any commercial or financial relationships that could be construed as a potential conflict of interest.

Copyright $\odot 2020$ Guo, Zhang, Yang, Xu, Fu, Liu, Li, Zhang and Xie. This is an open-access article distributed under the terms of the Creative Commons Attribution License (CC BY). The use, distribution or reproduction in other forums is permitted, provided the original author(s) and the copyright owner(s) are credited and that the original publication in this journal is cited, in accordance with accepted academic practice. No use, distribution or reproduction is permitted which does not comply with these terms. 